Vol. 18 (2009): 91-99.

\title{
Seed production of two meadow fescue cultivars differing in growth habit
}

\author{
Pirjo Mäkelä and Matti Kousa \\ Department of Applied Biology, PO Box 27, FI-00014 University of Helsinki, Finland \\ email:etunimi.sukunimi@helsinki.fi
}

\begin{abstract}
Meadow fescue (Festuca pratensis Huds.) is grown widely in the Nordic countries in forage grass mixtures. Locally adapted cultivars are preferred for establishment of mixed swards. Meadow fescue seed yield is determined by seed weight, the number of panicle bearing tillers, size of panicles and the number of fertile florets. We aimed to determine the differences in components of seed yield in two different meadow fescue cultivars differing in forage quality; Kalevi, released in 1979, and Fure, released in 1999. Biomass accumulation was monitored, numbers of fertile and sterile florets, and seeds were counted, and the forage quality was analysed. Seed quality was also analysed. Fure was leafier and accumulated more vegetative biomass than Kalevi. Kalevi had significantly more panicles than Fure, although Fure compensated for the lower number of panicles with increased panicle size. There were no differences in number of sterile and aborted florets between cultivars. Based on the results it seems that these two meadow fescue cultivars have a completely different strategy in seed production even though the final seed yield was not markedly different. It is apparent that meadow fescues have good ability to compensate among the components of seed yield. Long-term field experiments should be conducted to investigate the interactions between plant stand ecology, seed production and cultivation technology.
\end{abstract}

Key-words: biomass, Festuca pratensis, seed yield, yield formation

\section{Introduction}

In Finland, meadow fescue (Festuca pratensis Huds.) is the second most cultivated forage grass after timothy, Phleum pratense L. (Niemeläinen et al. 2000). It is grown in mixtures with other forage grasses, including timothy, tall fescue (Festuca arundinacea L.) and perennial rye-grass (Lolium perenne L.), and with red clover (Trifolium pratense L.). Meadow fescue has several advantages when grown in mixtures, such as its competitive ability, excellent 
regrowth ability, tolerance of intensive grazing and cutting, and high protein content (Havstad 1996a, 1996b, Havstad et al. 2004). In a red clover-timothy mixture, meadow fescue increases the overwintering ability of the sward. The overwintering ability can be increased further if locally adapted cultivars are used. However, it seems that the seed yield of meadow fescue has decreased (Fig. 1) in Finland and Norway over recent years, with consequent decrease in cultivation and seed production.

The vegetative and generative growth phases occur simultaneously in perennial grasses. Thus, the vegetative phase tillers producing leaves and the generative phase tillers producing seeds compete intensively for carbon and nitrogen assimilates. This inevitably decreases the seed yield. On the other hand, formation and growth of vegetative tillers is necessary for future seed formation (Chastain and Young III 1998). The seed yield of meadow fescue is determined by the number of panicle-bearing tillers, size of panicles, the number of fertile florets and seed weight. These in turn are affected by plant height, leaf area, plant dry mass, time of flowering, sturdiness of the stems and seed shed (Fang et al. 2004). In meadow fescue, the formation of panicle-bearing tillers begins in early autumn prior to the seed harvest year (Havstad et al.

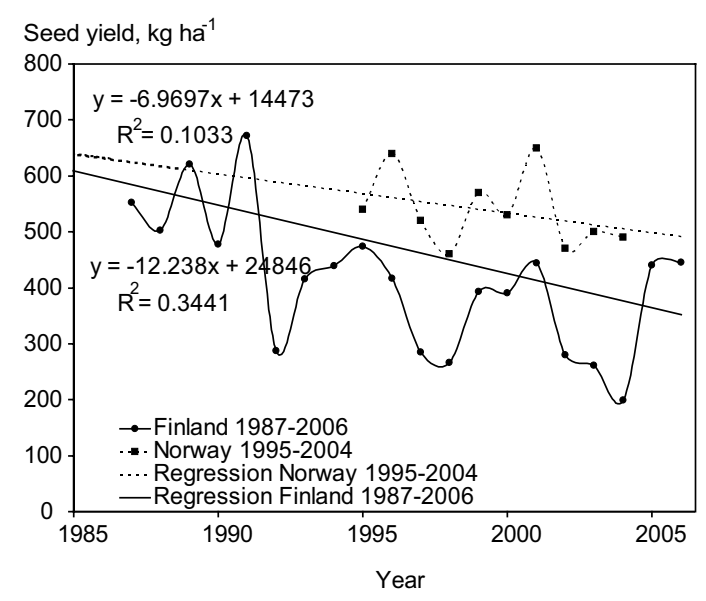

Fig. 1. Seed yields of meadow fescue from 1987 to 2006 in Finland and in Norway [data based on statistics of TIKE Finland (2005) and Mattilsynet Norway (2006)].
2004). Meadow fescue requires a double induction for flowering. Briefly, in the first phase, primary induction, tillers prepare for secondary induction and floret structures are not formed. Several complex processes related to induction are started at this stage. This phase requires a short day length $(<12$ h) and low temperatures $\left(3-15^{\circ} \mathrm{C}\right)$ for a period of 16 to 20 weeks (Heide 1994). In the second phase, secondary induction, floret structures develop. This requires long day length and higher temperatures $\left(15-21^{\circ} \mathrm{C}\right)$ than primary induction. Under high temperatures devernalisation may occur. After devernalisation, the tillers return to the vegetative phase (Aamlid 2005). The induction takes place regardless of the age of the tiller as long as the environment is favourable. The age of the plant slightly affects the initiation of induction (Havstad 1996a). It is noteworthy that tillers emerging after the induction period can produce panicles. In these cases, the tillers are induced during the bud-stage. Even though the plants can form panicles late in the autumn, most seed yield is produced by the panicles formed in the summer (Havstad 1996a, 1996b, Havstad et al. 2004).

Statistics indicate (Fig. 1) that the seed yield of meadow fescue in Finland has decreased over ten to fifteen years without reasonable explanation. The aim of this study was to investigate whether there are differences in seed production ability of two meadow fescue cultivars differing in their feed quality and year of release.

\section{Material and methods}

\section{Plant material and experimental design}

Field experiments were conducted at the Viikki experimental farm of the University of Helsinki $\left(60^{\circ} \mathrm{N}\right)$. Plant material consisted of two meadow fescue cultivars, Fure (released in 1999) and Kalevi (released in 1979). Plots were sown in spring 2005 with barley (Hordeum vulgare L.) as a cover crop. Seed rate for meadow fescue was $30 \mathrm{~kg} \mathrm{ha}^{-1}$ (germination percentage $>90 \%$ ) and for barley 500 
seeds $\mathrm{m}^{-2}$. The row width was $12.5 \mathrm{~cm}$. Plots were fertilised with $80 \mathrm{~kg} \mathrm{~N}^{-1}$ (Pellon Y3, N-P-K: 21-3-9, Kemira Grow-How Oyj). Barley was harvested and the straw was removed in the autumn. In spring 2006, the plots were fertilised with $100 \mathrm{~kg}$ $\mathrm{N} \mathrm{ha}^{-1}$ (Suomensalpietari, N-P-K: 26-0-1, Kemira Grow-How Oyj). The experiment was conducted in a completely randomised design with four replications. The cultivars were randomly assigned to 10 $\mathrm{m}^{2}$ plots $(8 \mathrm{~m} \times 1.25 \mathrm{~m})$.

\section{Sampling and analyses}

Accumulation of biomass was analysed four times by collecting a sample from each plot from a 30 $\mathrm{cm}$ row. The first sample was collected at the end of tillering stage and every second week thereafter. Samples were oven-dried at $80^{\circ} \mathrm{C}$ for two days and weighed. Number of panicles and florets per panicle were counted eight times, beginning at the flowering stage. Two $10 \mathrm{~cm}$ rows were cut $5 \mathrm{~cm}$ above the soil surface from each plot and the number of panicles and sterile and fertile florets per panicle was counted under microscope. Florets were idenfied as sterile if the floret structure was not complete (for instance stamens missing). Florets were identified as aborted if seed growth was not observed after anthesis under microscope. The weight of individual spikelets was also recorded. The spikelets were detached, oven-dried at $80{ }^{\circ} \mathrm{C}$ for two days and weighed. At maturity, a sample of $30 \times 30 \mathrm{~cm}$ was collected from each plot. Leaves, stems (including leaf sheath), and panicles were separated, ovendried at $80^{\circ} \mathrm{C}$ for two days and weighed. Number of tillers was recorded. Seeds were detached from the panicles, counted and weighed. The whole plot seed yield was harvested at maturity and dried to $14 \%$ moisture content. Thousand seed weight was calculated from three subsamples of 100 seeds.

For analysis of forage quality, samples were collected twice in 2006. The first sample was collected when digestibility (D-value, Artturi web service) was predicted to be $69 \%$ and the second sample was collected three days later (predicted D-value $67 \%$ ). For each sample three $30 \mathrm{~cm}$ rows per plot were cut $5 \mathrm{~cm}$ above the soil surface. Samples were analysed for primary and secondary dry matter, ash content, raw protein content and digestibility (D-value) at MTT Agrifood Research Finland in 2006. Primary dry matter was measured by drying the samples in an oven at $105^{\circ} \mathrm{C}$ for 20 hours and secondary dry matter after drying at 105 ${ }^{\circ} \mathrm{C}$ for 16 hours. Nitrogen content was analysed using the Kjeldahl method. The D-values were calculated after Huhtanen et al. (2006) from the in vitro solubility of organic matter, using a modified method described by Nousiainen et al. (2003). The results were calculated using a correction equation to convert pepsin-cellulase solubility values into in vivo digestibility using an equation based on a data set comprising results from Finnish in vivo digestibility trials.

\section{Statistics}

Differences in measured traits were established with SAS 9.14 variance analysis (PROC GLM). Further analyses included correlation between traits measured (PROC CORR), and stepwise regression analysis, which was used to determine the traits most affecting seed yield (PROC STEPWISE).

\section{Results}

The two cultivars studied did not differ significantly in their forage quality at the earlier sampling time, except for ash content, which was higher in Fure than in Kalevi (Table 1). At the second sampling, Kalevi had a higher D-value and primary dry matter content than Fure. The D-value of Kalevi decreased only $244 \mathrm{~g} \mathrm{~kg}^{-1} \mathrm{DM}$, whereas that of Fure decreased by $366 \mathrm{~g} \mathrm{~kg}^{-1} \mathrm{DM}$ within a three day interval between the samplings (Table 1).

The total number of florets and number of fertile florets in panicles was higher in Fure than in Kalevi. Most of the florets were set in the lowest part of the panicle (Fig. 2). Also, most fertile florets were set in the lowest parts of the panicle. Half of the fertile florets in Fure were set in the seven lowest branches and in Kalevi in the six lowest. Even 


\section{Mäkelä, P. \& Kousa, M. Seed production of meadow fescue}

Table 1. Feed quality parameters for Fure and Kalevi. Data are means of 4 measurements. Harvest I was done when the predicted D-value was $69 \%$, and harvest II was done three days later.

\begin{tabular}{lllcccc}
\hline Harvest & Cultivar & $\begin{array}{c}\text { D-value, } \\
\mathrm{g} \mathrm{kg}^{-1} \mathrm{DM}\end{array}$ & $\begin{array}{c}\text { Primary DM, } \\
\%\end{array}$ & $\begin{array}{c}\text { Secondary DM, } \\
\%\end{array}$ & $\begin{array}{c}\text { Ash content, } \\
\mathrm{g} \mathrm{kg}^{-1} \mathrm{DM}\end{array}$ & $\begin{array}{c}\text { Raw protein, } \\
\mathrm{g} \mathrm{kg} \mathrm{DM}^{-1} \mathrm{DM}\end{array}$ \\
\hline I & Fure & $699.1 \pm 2.7$ & $22.1 \pm 0.1$ & $94.5 \pm 0.1$ & $93.1 \pm 0.9$ & $168.0 \pm 4.3$ \\
& Kalevi & $695.9 \pm 0.9^{\text {ns }}$ & $22.6 \pm 0.3^{\text {ns }}$ & $94.5 \pm 0.1^{\mathrm{ns}}$ & $85.9 \pm 1.0^{* * * *}$ & $167.5 \pm 2.9^{\text {ns }}$ \\
II & Fure & $662.5 \pm 2.6$ & $23.4 \pm 0.1$ & $91.5 \pm 0.1$ & $85.4 \pm 1.9$ & $146.0 \pm 4.8$ \\
& Kalevi & $671.5 \pm 1.7^{*}$ & $24.9 \pm 0.1^{* * *}$ & $91.4 \pm 0.1^{\mathrm{ns}}$ & $84.4 \pm 1.4^{\mathrm{ns}}$ & $144.6 \pm 2.8^{\mathrm{ns}}$ \\
\hline
\end{tabular}

$\mathrm{DM}=$ dry matter

Statistically significant differences are indicated as follows: ns, $p>0.05 ; *, 0.05>p>0.01 ; * *, 0.01>p>0.001 ; * * *, p<0.001$.
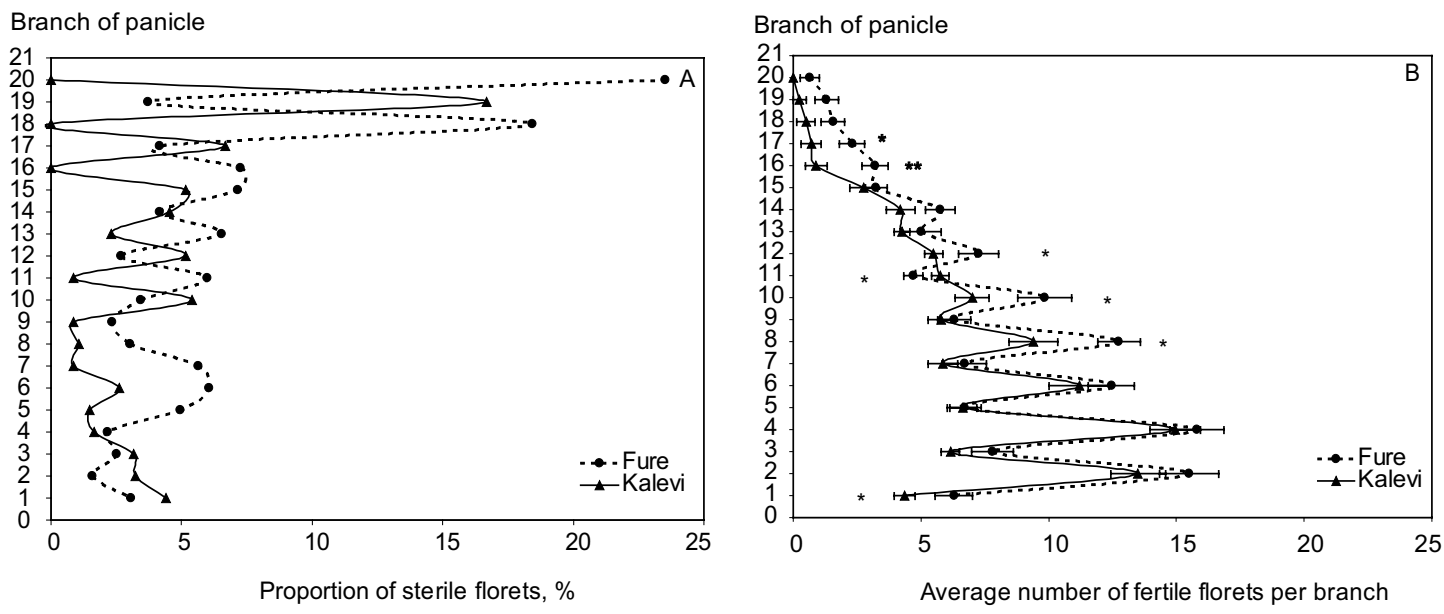

Fig. 2. Proportion of sterile (a) florets and number of fertile (b) florets in panicles of Fure and Kalevi at anthesis. Data are means of 20 measurements, bars indicate \pm SE. Statistically significant differences are indicated as follows: *, $0.05>p>0.01 ; * *, 0.01>p>0.001 ; * * *, p<0.001$.

though there were $50 \%$ more sterile florets in the panicles of Fure, the difference was not statistically significant. The number of sterile florets was highest on average in the middle of the panicle in both cultivars (Fig. 2). The dry weight accumulation of spikelets was recorded twice before full flowering and was approximately $3 \mathrm{mg}$. The spikelet dry weight began to increase markedly five to eight days after full flowering (Fig. 3). The spikelets were heavier in the lowest parts and lightest in the uppermost parts of the panicle (Fig. 3). Seed weight formed $86 \%$ of the panicle weight in Kalevi and $85 \%$ in Fure. The seed filling period was longer in Fure than in Kalevi. However, the seed-filling rate was higher in Kalevi than in Fure.
The only recorded significant difference in phytomass accumulation between the cultivars was recorded at the stem elongation phase, when Kalevi had accumulated more phytomass than Fure (Fig. 4). The observed difference levelled out at later growth stages. However, at maturity, Fure had more leaf mass (33\% of phytomass) than Kalevi (28\% of phytomass) (Fig. 4). On the other hand, Kalevi had more panicle mass (43\% of phytomass) than Fure (35\% of phytomass). Kalevi also had $19 \%$ more tillers, $47 \%$ more panicles and $21 \%$ more seeds than Fure at seed maturity (Table 2). Fure had 22\% more seeds per panicle than Kalevi, whereas the thousand seed weight of Kalevi was 7\% higher than that of Fure. However, the total seed yield did not 


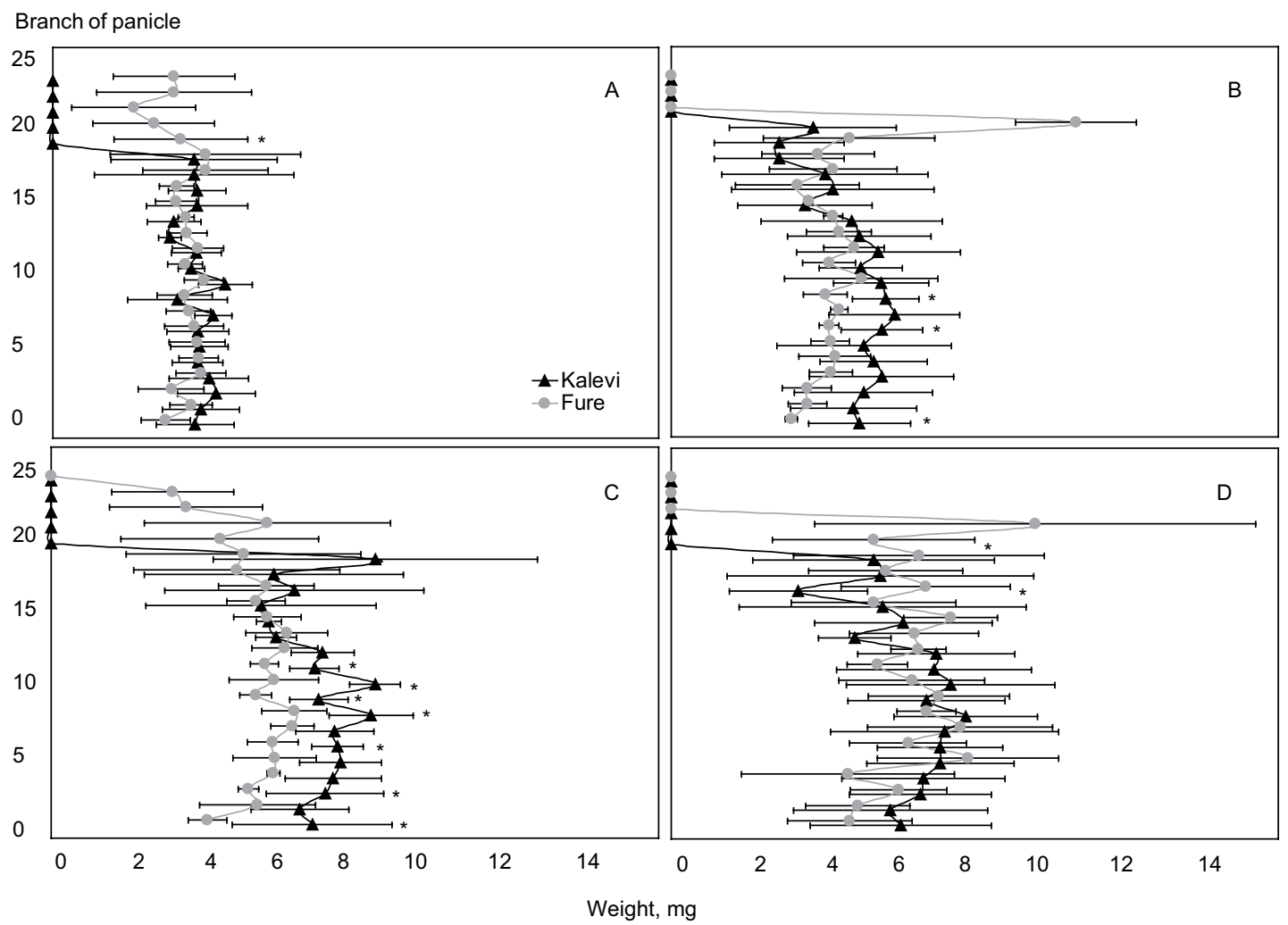

Fig. 3. Dry weight accumulation of spikelets in panicles of Fure and Kalevi. Two days after anthesis (a), 8 days after anthesis (b), 13 days after anthesis (c) and 15 days after anthesis (d). Data are means of 20 measurements, bars indicate \pm SE. Statistically significant differences are indicated as $*, 0.05>p>0.01$.

Dry weight, $\mathrm{g} \mathrm{m}^{-2}$

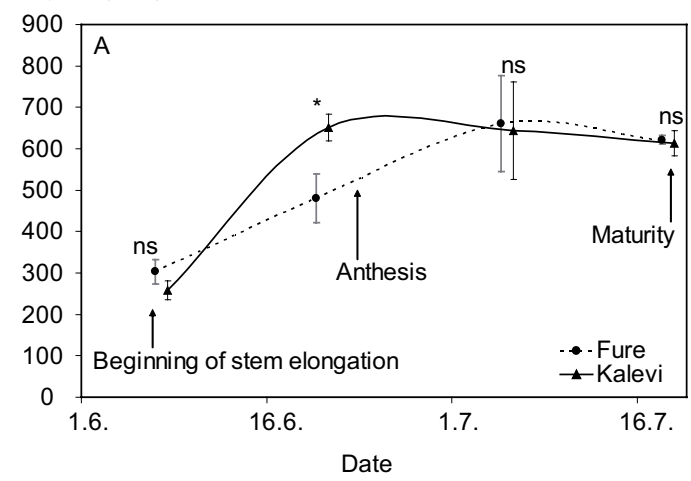

Dry weight, $\mathrm{g} \mathrm{m}^{-2}$

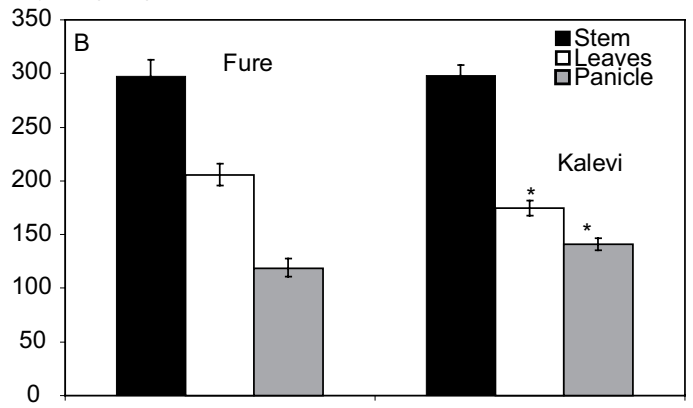

Fig. 4. Accumulation of total above-ground dry weight during the growing period (a) and dry weight of stems, leaves and panicles (b) for Fure and Kalevi at maturity in 2006. Data are means of 12 measurements, bars indicate \pm SE. Statistically significant differences are indicated as follows: $*, 0.05>p>0.01 ; * *, 0.01>p>0.001 ; * * *, p<0.001$. 


\section{Mäkelä, P. \& Kousa, M. Seed production of meadow fescue}

differ between the cultivars (Table 2). Harvest index of Kalevi was 19.7 and slightly lower, 16.3 in Fure.

In this study, the stepwise regression analysis revealed that the increase in seed yield of Kalevi derived mostly from crop phytomass before anthesis (Table 3). In contrast, increase in crop phytomass before anthesis decreased the seed yield of Fure. Moreover, the increase in seed weight per panicle in Fure resulted in decrease of the seed yield. In Kalevi, seed yield decreased significantly with increase in the number of panicles (Table 3).

\section{Discussion}

Increase in phytomass was faster in Kalevi than in Fure (Fig. 4). Kalevi reached maximum phytomass before anthesis, whereas in Fure the phytomass con- tinued to increase even after anthesis. This could be due to higher number of vegetative tillers of Fure. Kalevi produced more generative tillers (Table 2), which are known to increase dry weight quickly between the period from induction to beginning of flowering (Anslow and Green 1967). In both cultivars the stems constituted approximately $48 \%$ of the plant dry weight and the panicles 19-23\% (Fig. 4), which is similar to partitioning of dry weight in perennial rye-grass (Elgersma 1990). This difference between generative and vegetative tillers was also evident in the fodder quality. The fodder quality of both cultivars was similar at the first sampling (Table 1), being above the target values (Artturi web service). However, only three days later, the quality values had decreased below the target values. Meadow fescue has a rapid growth rhythm, due to which the proportion of straw increases significantly and the fodder becomes coarse (Havstad 1996a, 1996b). Also, even though the first fodder yield of the cultivars studied was similar, the total fodder

Table 2. Seed yield and its components for Fure and Kalevi. Data are means of 4-12 measurements. Seed yield was harvested from the whole plot, and shown at $14 \%$ moisture content.

\begin{tabular}{lcc}
\hline Trait & Fure & Kalevi \\
\hline Number of tillers $\mathrm{m}^{-2}$ & $2238 \pm 59$ & $2655 \pm 92^{* *}$ \\
Number of panicles $\mathrm{m}^{-2}$ & $1007 \pm 74$ & $1485 \pm 66^{* * *}$ \\
Seeds per panicle & $77 \pm 4$ & $63 \pm 3^{*}$ \\
1000 seed weight, g & $1.96 \pm 0.06$ & $2.10 \pm 0.01^{* * *}$ \\
Seed yield, $\mathrm{kg} \mathrm{ha}^{-1}$ & $747 \pm 55$ & $876 \pm 33^{\text {ns }}$ \\
\hline
\end{tabular}

Statistically significant differences are indicated as follows: $\mathrm{ns}, p>0.05 ; *, 0.05>p>0.01 ; * *, 0.01>p>0.001 ; * * *$, $p<0.001$.

Table 3. Contribution of primary components of crop growth and seed formation after the forward elimination of stepwise regression analysis to the seed yield. Dependent variable is seed yield.

\begin{tabular}{|c|c|c|c|c|c|c|c|}
\hline \multirow[b]{2}{*}{ Cultivar } & \multirow[b]{2}{*}{ Intercept } & \multicolumn{6}{|c|}{ Independent variable } \\
\hline & & First & & $\mathrm{R}^{2}$ & Second & & $\mathrm{R}^{2}$ \\
\hline Fure & 1487.07 & Phytomass $^{\mathrm{a}}$ & -2.01 & 0.98 & Panicle seed weight ${ }^{b}$ & -1291.92 & 1.00 \\
\hline Kalevi & 3340.43 & Phytomass & 1.27 & 0.58 & No. panicles ${ }^{\mathrm{c}}$ & -1.88 & 1.00 \\
\hline
\end{tabular}

${ }^{\mathrm{a}}$ phytomass $\mathrm{g} \mathrm{m}^{-2}$ at stem elongation phase

${ }^{\mathrm{b}}$ panicle seed weight, $g$

${ }^{c}$ panicles, number $\mathrm{m}^{-2}$ 
yield and the quality of fodder of Fure was higher than that of Kalevi (Kangas et al. 2002).

Differences in the number of florets per panicle between the cultivars could be due to differences in panicle size. In the uppermost parts of the panicle the dry weight of the spikelets varied markedly as the number of branches ranged from none to several. Fure had larger panicles than Kalevi, especially in the middle of the panicle and Fure had more florets in comparison with Kalevi (Fig. 2). More florets were set in the middle and lowest sections of the panicle in both cultivars (Fig. 2), similarly to perennial ryegrass (Elgersma 1990). Moreover, the number of sterile florets was highest in the middle of the panicle and the proportion of sterile florets was highest in the uppermost part of the panicle (Fig. 2), again similarly to perennial ryegrass (Elgersma 1990). Unlike in oat (Avena sativa L.), in which up to $80 \%$ of florets can abort (Peltonen-Sainio and Peltonen 1995), only 20\% of florets aborted in the meadow fescue cultivars studied (Fig. 2), as in perennial ryegrass (Elgersma 1990). The high number of florets and low number of sterile or aborted florets affected the number of seeds per panicle. Fure had more seeds per panicle than Kalevi (Table 2). Kalevi produced $60 \%$ and Fure $90 \%$ more seeds than meadow fescues on average, 40 (Nordestgaard 1981). However, Nordestgaard (1981) counted the number of seeds per panicle based on the actual harvested seed yield, number of panicles $\mathrm{m}^{-2}$ and thousand seed weight and thus, it is anticipated to be smaller than in this study in which all seeds were counted and harvesting and seed cleaning losses eliminated. As the number of panicles per area unit increases, usually the number of seeds per panicle decreases (Fairey and Lefkovitch 1999). This was observed in our study; Kalevi produced more panicles per square metre, but fewer seeds per panicle in comparison with Fure (Table 2). Moreover, Kalevi seemed to have a shorter period of seed filling in comparison with Fure since the spikelet weight began to increase at the beginning and decrease in the end more quickly after anthesis in Kalevi than in Fure, even though the final spikelet weights did not differ (Fig. 3). However, the thousand seed weight was higher in Kalevi than in Fure (Table 2), and thus,
Fure gained no benefit from a longer seed filling period.

The increase in panicle seed weight and phytomass before anthesis decreased the seed yield in Fure (Table 3). According to Fang et al. (2004), the seed weight per panicle in meadow fescue increases the seed yield. The observation concerning Fure is not completely contradictory to that of Fang et al. (2004) since the panicle seed weight depends on single seed weight and number of seeds per panicle. It seems, however, that increase in plant phytomass might result in severe shading of the lower parts of the plants and therefore decrease the source. This suggestion is further supported by the leafiness of Fure (Fig. 4). Moreover, the increase in panicle seed weight might have increased the sink demand, creating competition between the vegetative and generative plant parts. In perennial grasses the competition for assimilates between generative and vegetative plant parts is more marked than in cereals (Fang et al. 2004). The roots and leaves, in particular, compete with filling seeds for carbohydrates (Chastain and Young III 1998). The thousand seed weight was also lower in Fure than in Kalevi (Table 2), which further indicates that Fure provides a higher proportion of the assimilates to the vegetative parts during seed filling than Kalevi. Kalevi appears to be source-limited since an increase in number of panicles decreased the seed yield, whereas increase in phytomass before anthesis increased seed weight (Table 3 ). The increase in panicle number increases the demand for assimilates, which can be provided by increased plant phytomass, especially in the case of Kalevi, which is less leafy.

In conclusion, it seems that meadow fescue is able to compensate among the yield components effectively. Therefore, further enhancement of seed yield of these cultivars can only be achieved by getting more information on the interactions between plant stand ecology and cultivation techniques in long-term field experiments.

Acknowledgements. We would like to thank Kylvösiemensäätiö for financing the project, Semenat Oy for supplying the seed material. We are most grateful to Markku Tykkyläinen and Antti Tuulos for technical assistance. 
Mäkelä, P. \& Kousa, M. Seed production of meadow fescue

\section{References}

Aamlid T.S. 2005. A comparison between primary induction requirements in vegetatively propagated ramets and seedlings of Festuca pratensis and Festuca rubra. Acta Agriculturae Scandinavica. Section B, Soil and Plant Science 55: 299-303.

Anslow R.C. \& Green J.O. 1967. The seasonal growth of pasture grasses. Journal of Agricultural Science 68: 109-122.

Chastain T.G. \& Young III W.C. 1998. Vegetative plant development and seed production in cool-season perennial grasses. Seed Science Research 8: 295-301.

Elgersma A. 1990. Seed yield related to crop development and to yield components in nine cultivars of perennial ryegrass (Lolium perenne L.). Euphytica 49: 141-154.

Fairey N.A. \& Lefkovitch L.P. 1999. Crop density and seed production of tall fescue (Festuca arundinacea Schreber). 1. Yield and plant development. Canadian Journal of Plant Science 79: 535-541.

Fang C., Aamlid T.S., Jørgensen Ø. \& Rognli O.A. 2004. Phenotypic and genotypic variation in seed production traits within a full-sib family of meadow fescue. Plant Breeding 123: 241-246.

Havstad L.T. 1996a. Juvenility and flowering in Festuca pratensis Huds. 1. Effects of plant age, cultivar and duration of primary induction treatments. Norwegian Journal of Agricultural Sciences 10: 159-178.

Havstad L.T. 1996b. Juvenility and flowering in Festuca pratensis Huds. 2. Effects of light intensity, defoliation and duration of primary induction treatments. Norwegian Journal of Agricultural Sciences 10: 397-412.

Havstad L.T., Aamlid T.S., Heide O.M. \& Junttila O. 2004. Transfer of flower induction stimuli to non-exposed till- ers in a selection of temperate grasses. Acta Agriculturae Scandinavica. Section B, Soil and Plant Science 54: $23-30$.

Heide O.M. 1994. Control of flowering and reproduction in temperate grasses. New Phytologist 128: 347-362.

Huhtanen P., Nousiainen J. \& Rinne M. 2006. Recent developments in forage evaluation with special reference to practical applications. Agricultural and Food Science 15: 293-323.

Kangas A., Laine A., Niskanen M., Salo Y., Vuorinen M., Jauhiainen L. \& Mäkelä L. 2002. Virallisten lajikekokeiden tulokset 1994-2001. MTT:n selvityksiä 2. Jokioinen: Maa- ja elintarviketalouden tutkimuskeskus. 282 p.

Mattilsynet. 2006. Gjennomsnitt avlingar pr. daa godkjent areal, Engvekster. Statens tilsyn for planter, fisk, dyr och næringsmidler. (in Norwegian).

Niemeläinen O., Jauhiainen L. \& Miettinen E. 2000. Yield profile of tall fescue (Festuca arundinacea) in comparison with meadow fescue ( $F$. pratensis) in Finland. Grass and Forage Science 56: 249-258.

Nordestgaard A. 1981. Various time of application of nitrogen in spring in connection with seed production of meadow fescue (Festuca pratensis). Tidsskrift for Plantealv 85: 1-12.

Nousiainen J., Rinne M., Hellämäki M. \& Huhtanen P. 2003. Prediction of the digestibility of the primary growth of grass silages harvested at different stages of maturity from chemical composition and pepsin-cellulase solubility. Animal Feed Science and Technology 103: 97-111.

Peltonen-Sainio P. \& Peltonen J. 1995. Floret set and abortion in oat and wheat under high and low nitrogen regimes. European Journal of Agronomy 4: 253-262.

TIKE. 2005. Käytössä oleva maatalousmaa 2005. Maaja metsätalousministeriön tietopalvelukeskus. (in Finnish). http://www.matilda.fi. Cited 19.12.2006/Updated 11.12.2008. 
Vol. 18 (2009): 91-99.

\title{
SELOSTUS
}

\section{Kahden kasvutavaltaan eroavan nurminatalajikkeen siemensadon muodostuksen erot}

\author{
Pirjo Mäkelä ja Matti Kousa \\ Helsingin yliopisto
}

\begin{abstract}
Nurminataa (Festuca pratensis Huds.) viljellään laajalti pohjoismaissa rehunurmiseoksissa. Seosnurmien perustamiseen halutaan usein käyttää paikallista alkuperää olevaa siementä mahdollisuuksien mukaan. Nurminadan siemensato määräytyy kasvustossa olevien röyhyllisten versojen, röyhyjen koon ja röyhyssä olevien fertiilien kukkien määrän sekä siementen painon mukaan. Tämän työn tarkoituksena oli tutkia, onko kahden kasvutavaltaan poikkeavan nurminatalajikkeen siemensadon muodostuksessa eroja. Lajikkeina olivat vuonna 1979 kauppaan laskettu Kalevi ja vuonna 1999 kauppaan laskettu Fure. Kasvustoista seurattiin biomassan muodostusta, laskettiin fertiilien ja steriilien kukkien lukumäärä sekä siementen lukumäärä ja analysoitiin kasvustojen rehulaatu. Lisäksi
\end{abstract}

määritettiin siemensadon laatu. Fure oli lehtevämpi ja muodosti enemmän vegetatiivista massaa kuin Kalevi. Kalevi muodosti ensimmäisenä satovuotena enemmän röyhyjä kuin Fure, mutta Fure kompensoi vähäisempää röyhyjen määrää suuremmalla röyhyjen koolla. Steriilien ja abortoituneiden kukkien lukumäärässä ei lajikkeiden välillä ollut eroa. Tämän kokeen perusteella nurminata lajikkeet erosivat toisistaan täysin siemensadon muodostuksessa vaikkakaan merkitsevää eroa lopullisessa siemensadossa ei ollut. Nurminadalla näyttääkin olevan erinomainen kyky kompensoida siemensadon satokomponentteja. Siemensatojen nostamiseksi kasvustoekologian ja viljelytekniikan yhdysvaikutus tulisi selvittää monivuotisissa kokeissa. 